\title{
Alloy Selection for Accident Tolerant Fuel Cladding in Commercial Light Water Reactors
}

\begin{abstract}
RAUL B. REBAK
As a consequence of the March 2011 events at the Fukushima site, the U.S. congress asked the Department of Energy (DOE) to concentrate efforts on the development of nuclear fuels with enhanced accident tolerance. The new fuels had to maintain or improve the performance of current $\mathrm{UO}_{2}$-zirconium alloy rods during normal operation conditions and tolerate the loss of active cooling in the core for a considerably longer time period than the current system. DOE is funding cost-shared research to investigate the behavior of advanced steels both under normal operation conditions in high-temperature water [e.g., $\left.561 \mathrm{~K}\left(288{ }^{\circ} \mathrm{C}\right)\right]$ and under accident conditions for reaction with superheated steam. Current results show that, under accident conditions, the advanced ferritic steels (1) have orders of magnitude lower reactivity with steam, (2) would generate less hydrogen and heat than the current zirconium alloys, (3) are resistant to stress corrosion cracking under normal operation conditions, and (4) have low general corrosion in water at $561 \mathrm{~K}\left(288^{\circ} \mathrm{C}\right)$.
\end{abstract}

DOI: $10.1007 / \mathrm{s} 40553-015-0057-6$

(C) ASM International (ASM) and The Minerals, Metals \& Materials Society (TMS) 2015

\section{INTRODUCTION}

Following the north-east Japan events at Fukushima in March 2011, the U.S. Department of Energy Office of Nuclear Energy (DOE-NE) is working to develop nuclear fuels and claddings with enhanced accident tolerance. ${ }^{[1]}$ A fuel may be defined as having enhanced accident tolerance if, in comparison with the current $\mathrm{UO}_{2}$-zirconium alloy system, it can tolerate loss of active light water cooling in the reactor core for a considerably longer time period while maintaining or improving fuel performance during normal operations and operational transients, as well as in design basis and beyond design-basis events. The enhanced fuel material should have

- Improved reaction kinetics with steam (generate less exothermic heat);

- Slower hydrogen production rate;

- Improved cladding and fuel properties;

- Enhanced retention of fission products.

The commercial nuclear energy in the United States had its origin in the nuclear navy. From 1948 to 1950, Admiral Rickover was able to persuade the US Atomic Energy Commission to transfer the main development of a prototype nuclear power reactor from national laboratories like Argonne to commercial enterprises like General Electric Knolls Laboratory in Schenectady and Westinghouse Bettis Laboratory near Pittsburgh. ${ }^{[2]}$ Eventually, to achieve his navy project goal of a submarine reactor, Rickover was able to have a group

RAUL B. REBAK, Corrosion Engineer, is with GE Global Research, One Research Circle, Schenectady, NY 12309. Contact e-mail: rebak@ge.com.

Manuscript submitted August 3, 2014.

Article published online September 16, 2015 of laboratories work together, including Argonne, Bettis, Idaho, and Knolls. ${ }^{[2]}$ Toward the end of the 1940s, the navy was looking for a material with a low affinity for neutrons to clad the uranium fuel elements against corrosion by hot water. The navy originally adopted zirconium-based alloys over stainless steels for the fuel cladding mainly because of the higher transparency to neutrons of the former making the reactors more compact for submarine applications. ${ }^{[3,4]}$ The use of zirconium as a cladding material for nuclear fuel in the US navy was practically unilaterally enforced by Rickover. $^{[2]}$ In spite of the thermal neutron cross section of stainless steels being approximately 12 to 16 times higher than for zirconium alloys, it is now understood that the fuel enrichment penalty incurred by the use of stainless steel cladding can be partially overcome by using thinner wall-advanced stainless cladding. ${ }^{[4,5]}$ The best steels would be the ferritic since they do not contain the high neutron absorbing nickel. ${ }^{[5]}$ Ferritic steels are also resistant to environmentally assisted cracking in high-temperature water typical of BWR and PWR reactors. ${ }^{[6]}$ The average thermal neutron absorption cross section for a zirconium alloy would be 0.20 barns; for the traditional type $304 \mathrm{SS}$, it would be 2.86 barns; for the high nickel type $310 \mathrm{SS}$, it would be 3.21 barns; and for the ferritic APMT alloy, the cross section would be 2.47 barns. $^{[5]}$

Zirconium-based alloys performed well as fuel cladding in commercial power reactors for more than five decades. Zirconium alloys have good corrosion resistance in high-temperature water, and they are resistant to environmental cracking. At the beginning of the nuclear power development program, it was found that higher carbon austenitic stainless steels (such as type 304 SS) suffered environmentally assisted cracking [stress corrosion cracking (SCC)] in high-temperature water, especially in the sensitized areas associated to welds. 
Table I. Physical Properties of Ferritic and Austenitic Steels

\begin{tabular}{llc}
\hline Steel & \multicolumn{1}{c}{$\begin{array}{c}\mathrm{CTE} 273 \mathrm{~K} \\
\text { to } 811 \mathrm{~K}\left(0{ }^{\circ} \mathrm{C} \text { to } 538{ }^{\circ} \mathrm{C}\right) \mu \mathrm{m} / \mathrm{m} /{ }^{\circ} \mathrm{C}\end{array}$} & $\begin{array}{c}\text { Thermal Conductivity } \\
\text { at } 373 \mathrm{~K}\left(100{ }^{\circ} \mathrm{C}\right)(\mathrm{W} / \mathrm{m} \mathrm{K})\end{array}$ \\
\hline Zircaloy-2 & $8.32 \& 15.7($ orientation dependent $)$ & 13.8 \\
Ferritic type $430(16 \mathrm{pct} \mathrm{Cr})$ & 11.4 & 23.9 \\
Austenitic type $304 \mathrm{~L}(18 \mathrm{pct} \mathrm{Cr})$ & 18.4 & 16.2 \\
\hline
\end{tabular}

That is, little further research was conducted on stainless steels regarding their application as cladding material. Six decades later, it is now understood that highstrength ferritic stainless steels are resistant to environmental cracking and irradiation damage, which would not limit their application as fuel cladding in light water reactors. ${ }^{[6]}$ Moreover, current significant progress in steelmaking practices shows that the chemical purity in modern steels can be highly controlled. Similarly, there is an increased ability in the fabrication of these advanced steels into thin-walled tubes, including readily joining (welding) by several techniques.

Terrani et al. cite several uses in the industry of non-zirconium alloys as fuel cladding, including type 304, 316, and 347 austenitic stainless steels and austenitic nickel-based alloys such as Inconel 600 and Incoloy $800{ }^{[4]}$ Austenitic type 304 SS fuel cladding was used for some time in US commercial light water reactors, for example, at the Connecticut Yankee and San Onofre 1 power stations. ${ }^{[7]}$ The wall thickness for the austenitic stainless steel cladding was in the order of $0.5 \mathrm{~mm}$. The early cracking of type of 304 SS was linked to sensitization due to welding of high carbon alloys. The cracking phenomenon of austenitic sensitized stainless steels is now well understood and controlled, and it is not a current concern in light water reactors.

One of the alternatives for the fuel cladding could be using advanced ferritic steels (such as $\mathrm{Fe}-\mathrm{Cr}$-Al alloys) since earlier concerns about austenitic stainless steels suffering SCC and radiation damage can be now retired. The advanced ferritic steels may also have an advantage over zirconium-based alloys under severe accident conditions such as reaction with superheated steam.

\section{A. Behavior of Ferritic and Austenitic Steels in Light Water Reactors}

Austenitic stainless steels (SS) such as types 304 and 316 are highly susceptible to SCC in chloride containing environments, especially at temperatures higher than $333 \mathrm{~K}\left(60{ }^{\circ} \mathrm{C}\right) \cdot{ }^{[8]}$ The most common tests used in the industry to determine susceptibility to chloride cracking are immersion of U-bend specimens (ASTM G 30) into hot solutions of chloride salts including magnesium chloride or sodium chloride (ASTM G 36 and G 123). Ferritic stainless steels such as types 405 and 430 are highly resistant to SCC in hot chloride solutions. ${ }^{[8,9]}$

Austenitic stainless steels such as type 304L SS, 308, 316L SS, 321, and 347 are used worldwide as construction materials for light water power reactors. ${ }^{[10]}$ In the USA, the most common austenitic alloy may be type
304 SS (UNS S30403), and in Japan, the preferred stainless steel is type 316 (S31603). European countries such as Germany may prefer to use titanium (Ti) or niobium (Nb)-stabilized types of stainless steel such as type 321 (S32100) and 347 (S34700). Austenitic stainless steels are susceptible to SCC in boiler water reactor (BWR) service and in a lesser extent in pressurized water reactor (PWR) service. ${ }^{[10]}$

Austenitic stainless steel (SS) core internal components are susceptible to irradiation-assisted stress corrosion cracking (IASCC) during service in nuclear power plants' light water reactors. ${ }^{[1-13]}$ One of the effects of irradiation is the hardening of the SS due to modifications in the dislocation distribution in the alloy. ${ }^{[14,15]}$ Irradiation also alters the local chemistry of these austenitic alloys, for example, in the vicinity of grain boundaries by a mechanism of radiation-induced segregation. The segregation or depletion phenomena at or near grain boundaries may enhance the susceptibility of these irradiated alloys to SCC. ${ }^{[16,17]}$ The effect of the IASCC on austenitic stainless steels may impact the life extension of currently operating light water reactors due to the progressive dose accumulation. ${ }^{[18]}$

In nuclear power plant applications, ferritic steels have superior void swelling resistance because they experience delayed void nucleation, and they sustain less than 2 pct swelling even at irradiation levels close to 200 dpa. ${ }^{[19]}$ On the other hand, austenitic stainless steels such as type 304 undergo the onset of significant void swelling and possible embrittlement at dose rates in the order of $20 \mathrm{dpa}^{[16]}$ Besides the higher resistance of ferritic steels to radiation damage, other benefits that could make these steels more attractive than the austenitic stainless steels in nuclear applications include as follows: (1) Ferritic materials have lower cost since they do not contain nickel (Ni) and generally contain lower chromium (Cr), (2) They do not contain Ni or cobalt $(\mathrm{Co})$ that could be become activated in commercial reactors, (3) They offer a lower coefficient of thermal expansion (CTE), which matches the CTE of pressure vessel ferritic alloys such as type A508, A516, or A533, and (4) Ferritic steels have higher thermal conductivity for heat transfer capabilities (Table I).

\section{B. Reaction of Cladding Materials with Steam}

In the case of a loss of coolant accident (LOCA), such as in the Fukushima Daiichi situation, the cladding of the fuel will be exposed to steam. The zirconium alloy plus steam reaction has been widely studied under LOCA scenarios. ${ }^{[4,20-25]}$ Zircaloy oxidizes in the 
presence of steam to form zirconia and hydrogen following an exothermic reaction:

$$
\begin{aligned}
& \mathrm{Zr}+2 \mathrm{H}_{2} \mathrm{O} \rightarrow \mathrm{ZrO}_{2}+2 \mathrm{H}_{2} \\
& \Delta \mathrm{H}=-586 \mathrm{~kJ} / \mathrm{mole}(-140 \mathrm{kcal} / \mathrm{mole}) .
\end{aligned}
$$

According to Baker and Just, the chemical heat generated by the reaction of zirconium and steam in (Eq. [1]) could exceed the nuclear heat generation during a destructive nuclear transient. Moreover, the hydrogen generated by the reaction could give rise to a pressure surge and might subsequently react explosively with air. $^{\text {[20] }}$

All the ferrous materials listed in Table II, including ferritic steel T91, have lower reaction kinetics with steam than Zircaloy-2. The oxidation behavior of iron-based alloys in steam was recently reviewed and updated comparing to the behavior of zirconium alloys. ${ }^{[4,25]}$ At $1473 \mathrm{~K}\left(1200{ }^{\circ} \mathrm{C}\right)$, the degradation of APMT was practically nil (no mass change) after 8 hours exposure at $1273 \mathrm{~K}\left(1000{ }^{\circ} \mathrm{C}\right)$, while the degradation of Zircaloy-2 was complete for the same period of time. ${ }^{[25]}$ APMT offers extraordinary resistance to reaction with steam at temperatures higher than $1273 \mathrm{~K}\left(1000{ }^{\circ} \mathrm{C}\right)$ because it allows first for the formation of a protective $\mathrm{Cr}_{2} \mathrm{O}_{3}$ scale which subsequently allows for the formation of a continuous protective $\mathrm{Al}_{2} \mathrm{O}_{3}$ scale between the metal and the $\mathrm{Cr}_{2} \mathrm{O}_{3}$ scale. It is this $\mathrm{Al}_{2} \mathrm{O}_{3}$ scale what protects the alloy against further oxidation in steam. ${ }^{[25-27]}$ Cheng et al. studied the oxidation behavior of several new cladding candidates (SiC, stainless steels 304 and 317, alloy PM 2000 and iron-based alloys with 15 to $25 \mathrm{pct} \mathrm{Cr}$ ) at $1073 \mathrm{~K}, 1273 \mathrm{~K}$, and $1473 \mathrm{~K}\left(800{ }^{\circ} \mathrm{C}, 1000{ }^{\circ} \mathrm{C}\right.$, and $\left.1200{ }^{\circ} \mathrm{C}\right) .{ }^{[27]}$ They concluded that aluminum in the PM 2000 alloy formed a very protective alumina layer which significantly reduced the mass loss compared to the other materials under superheated steam conditions. ${ }^{[27]}$ Pint et al. also showed the effect of the content of $\mathrm{Cr}$ on the degradation of ferrous alloys. ${ }^{[25]}$ It was reported that the content of $\mathrm{Cr}$ is important and that, in the absence of $\mathrm{Al}$, at least a 25 pct of $\mathrm{Cr}$ may be required in the iron alloy to offer protection against steam. ${ }^{[25]}$ However, it is likely that if the alloy also contains approximately 5 pct $\mathrm{Al}$, lower amount of $\mathrm{Cr}$ may be needed to offer a similar resistance to oxidation.
The objective of the present work is to compare the environmental behavior of advanced steels to the behavior of the currently used zirconium-based alloys. The comparison will include behavior under (a) normal operation conditions and (b) under accident conditions such as LOCA.

\section{EXPERIMENTS AND RESULTS}

The aim of the current research was to characterize the behavior of advanced steels as candidate cladding materials in comparison to the behavior of one current zirconium alloy (Zircaloy-2). Table II shows the list of alloys that currently are being studied. The characterization studies are being performed both under (a) normal operation conditions [e.g., water at $561 \mathrm{~K}$ $\left(288^{\circ} \mathrm{C}\right)$ ], and (b) accident conditions (e.g., $100 \mathrm{pct}$ steam at $\left.>1073 \mathrm{~K}\left(>800{ }^{\circ} \mathrm{C}\right)\right)$. Other commercial zirconium alloys such as Zirlo and Zircaloy-4 are used in the commercial nuclear power industry, ${ }^{[28]}$ which may have a different behavior than Zircaloy-2.

\section{A. Behavior of Materials Under Normal Operation Conditions}

Under normal operation conditions, the cladding may not breach releasing fission products into the water. That is, similarly to the actual zirconium-based alloys, the candidate replacement alloys should not corrode excessively in water at $\sim 573 \mathrm{~K}\left(\sim 300{ }^{\circ} \mathrm{C}\right)$ nor suffer environmentally assisted cracking under similar conditions. The life of a fuel bundle in a commercial reactor is generally less than 10 years, that is, under normal operation conditions, the cladding should be able to survive for this period of time.

It can be anticipated that general corrosion of the advanced steels materials would be in the acceptable group of alloys for cladding applications. Coupons of the candidate materials are being tested for general corrosion under laboratory-simulated normal operation conditions of commercial light water reactors. Four sets of autoclaves are being used (Table III). The degradation of the immersion coupons is being evaluated by weight (mass) change, standard metallographic procedures, and surface analysis techniques. Corrosion behavior is also being evaluated by using electrochemical techniques such as monitoring the corrosion

Table II. Studied Alloys for Accident Tolerant Cladding in Light Water Reactors

\begin{tabular}{lll}
\hline Alloy & & \multicolumn{1}{c}{ Nominal Composition } \\
\hline Zircaloy-2 & $\mathrm{A}$ & $\mathrm{Zr}+1.2-1.7 \mathrm{Sn}+0.07-0.2 \mathrm{Fe}+0.05-0.15 \mathrm{Cr}+0.03-0.08 \mathrm{Ni}$ \\
Ferritic steel T91 & $\mathrm{B}$ & $\mathrm{Fe}+9 \mathrm{Cr}+1 \mathrm{Mo}+0.2 \mathrm{~V}$ \\
Ferritic steel HT9 & $\mathrm{C}$ & $\mathrm{Fe}+12 \mathrm{Cr}+1 \mathrm{Mo}+0.5 \mathrm{Ni}+0.5 \mathrm{~W}+0.3 \mathrm{~V}$ \\
Nanostructured ferritic alloy NFA & $\mathrm{D}$ & $14 \mathrm{YWT} \mathrm{or} \mathrm{Fe}+14 \mathrm{Cr}+0.4 \mathrm{Ti}+3 \mathrm{~W}+0.25 \mathrm{Y}_{2} \mathrm{O}_{3}$ \\
MA956 & $\mathrm{E}$ & $\mathrm{Fe}+18.5-21.5 \mathrm{Cr}+3.75-5.75 \mathrm{Al}+0.2-0.6 \mathrm{Ti}+0.3-0.7 \mathrm{Y}_{2} \mathrm{O}_{3}$ \\
APMT & $\mathrm{G}$ & $\mathrm{Fe}+22 \mathrm{Cr}+5 \mathrm{Al}+3 \mathrm{Mo}$ \\
EBRITE-S44627 & $\mathrm{H}$ & $\mathrm{Fe}+25-27.5 \mathrm{Cr}+1 \mathrm{Mo}+0.17(\mathrm{Ni}+\mathrm{Cu})$ \\
Alloy 33-R20033 & $\mathrm{J}$ & $33 \mathrm{Cr}+32 \mathrm{Fe}+31 \mathrm{Ni}+1.6 \mathrm{Mo}+0.6 \mathrm{Cu}+0.4 \mathrm{~N}$ \\
\hline
\end{tabular}


Table III. Immersion Tests Under Simulated Normal Operation Conditions

\begin{tabular}{lcc}
\hline Autoclave & Test Conditions at GE GRC & Alloys Under Testing \\
\hline $2584 \mathrm{~S}-2$ & simulated PWR, high purity water, 330 ${ }^{\circ} \mathrm{C}$ & T91, 14YWT, APMT \\
$2584 \mathrm{~S}-5$ & simulated BWR, hydrogen water chemistry $(63 \mathrm{ppb} \mathrm{H})$, & T91, 14YWT, APMT \\
& $561 \mathrm{~K}\left(288^{\circ} \mathrm{C}\right)$ & T91, 14YWT, APMT \\
$2584 \mathrm{~S}-6$ & simulated BWR, normal water chemistry $(2000 \mathrm{ppb} \mathrm{O})$, & Zircaloy-2, T91, HT9, \\
& $561 \mathrm{~K}\left(288^{\circ} \mathrm{C}\right)$ & $14 \mathrm{YWT}$ NFA, MA956, \\
$2520 \mathrm{~S}-14$ & simulated BWR, normal water chemistry $\left(2000 \mathrm{ppb} \mathrm{O}_{2}\right)$, & APMT, Ebrite, Alloy 33 \\
& $561 \mathrm{~K}\left(288^{\circ} \mathrm{C}\right)$ &
\end{tabular}

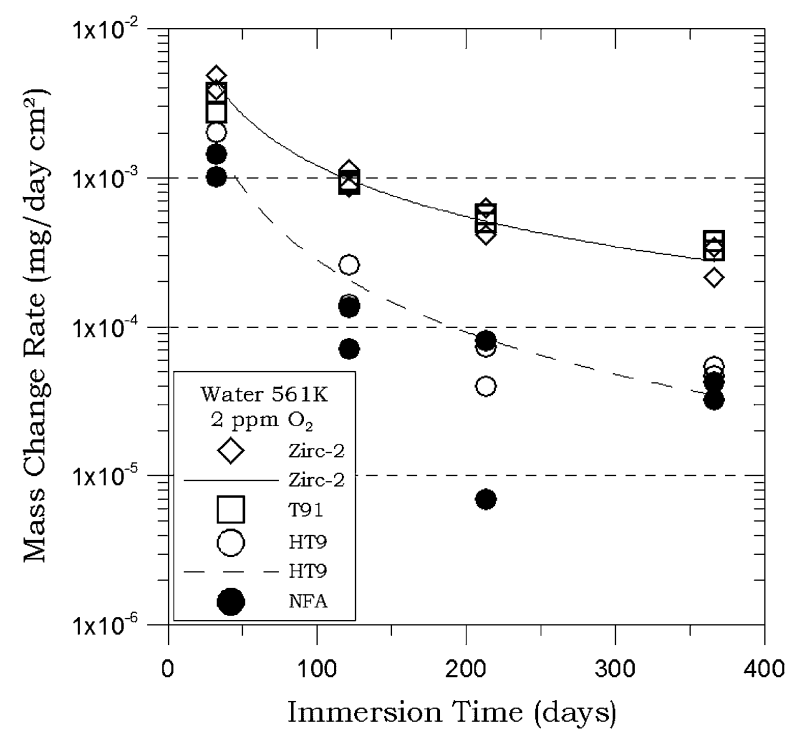

Fig. 1-Mass change per unit area and unit time for Zircaloy-2, T91, HT9, and NFA coupons exposed to pure water $+2 \mathrm{ppm} \mathrm{O}_{2}$ at $561 \mathrm{~K}\left(288^{\circ} \mathrm{C}\right)$ for a total time of 366 days.

potential as a function of time. The corrosion potentials of coupons of all the alloys (including $\mathrm{Pt}$ ) were continuously monitored using a zirconia membrane reference electrode containing copper and copper oxide, whose reference potential is $273 \mathrm{mV}$ higher than the standard hydrogen electrode (SHE) in pure water at $561 \mathrm{~K}$ $\left(288^{\circ} \mathrm{C}\right)$. In all the autoclave systems (S-2, S-5, S-6, and $\mathrm{S}-14)$, the water was recirculated at a flow rate of $100 \mathrm{~cm}^{3} / \mathrm{min}$ and reconditioned (filtered) before entering again the autoclaves.

Results from autoclaves S-2, S-5, and S-6 are not reported here. Figures 1 and 2 show the mass (weight) change for the alloys exposed to autoclave S-14 for incremental periods of $32,121,213$, and 366 days. The mass change is reported as mass gained per unit area per day. Figure 1 shows the mass change rate for two coupons each of Zircaloy-2 (the current baseline material for cladding in commercial light water reactors) and the newly studied materials T91, HT9, and nano-ferritic alloy (NFA) (Table II). As the exposure time increased, the rate of mass gain for the four alloys decreased, showing that a film may have developed on the surface that slowed down the rate of material degradation (Figure 1). Figure 1 also shows that up to 1 year exposure, the mass change for T91 (9Cr1Mo) was comparable to the mass change for Zircaloy-2. The mass

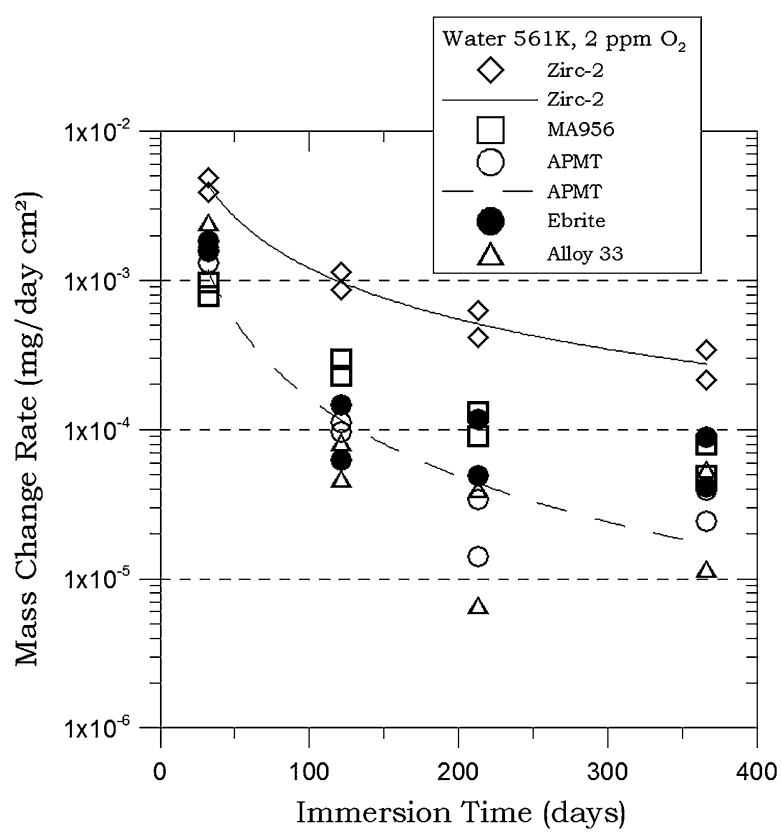

Fig. 2-Mass change per unit area and unit time for Zircaloy-2, MA956, APMT, Ebrite, and Alloy 33 coupons exposed to pure water $+2 \mathrm{ppm} \mathrm{O}_{2}$ at $561 \mathrm{~K}\left(288^{\circ} \mathrm{C}\right)$ for a total time of 366 days.

change rate for HT9 (12Cr1Mo) and NFA (14Cr) was lower than for T91. That is, all the tested alloys in Figure 1 showed equal or better corrosion resistance performance than the current Zircaloy-2 material under normal operation conditions. Figure 1 also shows the mass change trend according to a power fit for both Zircaloy-2 and HT9.

Figure 2 shows the mass change rate for two coupons each of Zircaloy-2 (the current baseline material for cladding in commercial light water reactors) and the newly studied materials MA956, APMT, Ebrite, and Alloy 33 (Table II). It also shows the power law fit for the mass change rate for Zircaloy-2 and APMT. It is clear again that all the new candidate alloys investigated in Figure 2 had a mass gain rate lower than that for Zircaloy-2. The data for 1 year exposure show that the mass gain rate for APMT was approximately one order of magnitude lower than for Zircaloy-2.

Figure 3 shows the corrosion potential as a function of time for eight materials including Zircaloy-2 and platinum. The lowest corrosion potential (most active) corresponded to Zircaloy-2, and the highest corrosion potential (most noble) corresponded to platinum. All 
the seven iron-containing materials had corrosion potentials that were in a narrow potential band of less than $50 \mathrm{mV}$. The lowest potential of the seven iron-containing materials was for T91 (9Cr1Mo). This agrees well with the mass gain as a function of time shown in Figure 1.

\section{B. Susceptibility to Environmental Cracking}

Table IV shows information on compact tension specimens made using non-irradiated materials, which were tested for resistance to environmental cracking. ${ }^{[6,27]}$

Most of the $0.5 \mathrm{~T}$ CT specimens were machined from the plates so that the notch in the specimen was placed in the SL direction of the plate (ASTM E399). Most of the materials were cold forged $(\mathrm{CF})$ by 20 pct, which increases their yield strength. The 20 pct cold reduction was performed to compare crack propagation results with the literature data for austenitic steels, which are normally cold reduced. (Cold reduction is used to accelerate crack propagation rate and, therefore, minimize the time required for testing). A cold reduction of 20 pct may correlate well with strains found in the welding of thick sections. For a plate material, the SL direction should be the most susceptible to environmentally assisted cracking, since the crack will have a

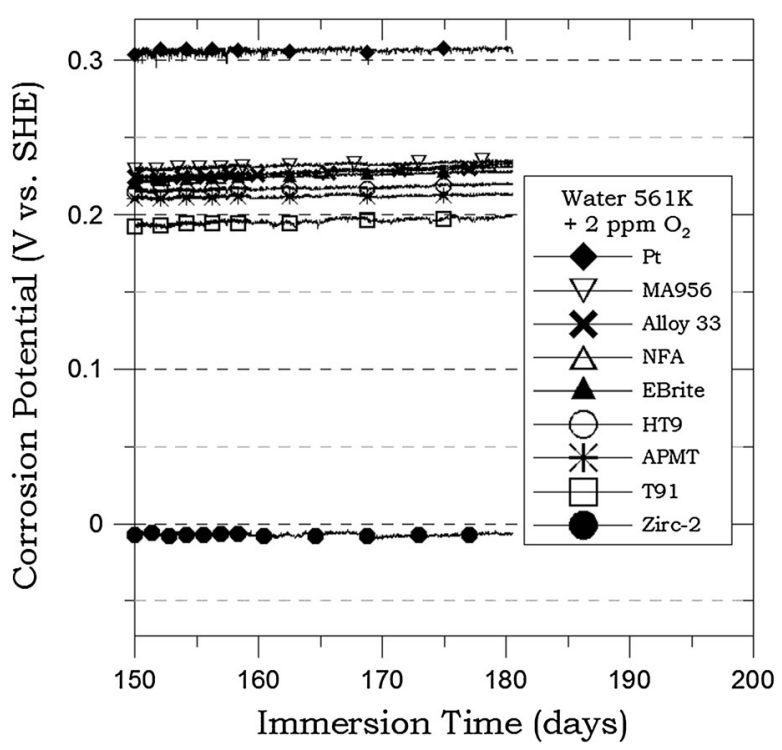

Fig. 3-Corrosion potential of Pt, Zircaloy-2, and seven iron-containing alloys exposed to pure water $+2 \mathrm{ppm} \mathrm{O}_{2}$ at $561 \mathrm{~K}\left(288^{\circ} \mathrm{C}\right)$. tendency to separate the material along pre-existing rolling lines.

$0.5 \mathrm{~T}$ compact type specimens were machined with 5 pct side grooves on each side. The CT specimens were instrumented with platinum current, and potential probe leads for dc potential drop crack length measurements. In this technique, current flow through the sample was reversed about once per second primarily to reduce measurement errors associated with thermocouple effects and amplifier offsets. The test was computer controlled using inputs from the relationship between the measured potential and crack length. Data were stored in a permanent disk file typically once every 0.69 hour. In addition to the data record number, total elapsed and incremental time, and crack length, the system measured and stored temperature, current, corrosion potential, dissolved gases, influent and effluent conductivity, load and time/date. Additionally, both operator and automated program messages describing changes in the test conditions and test status were a permanent part of the data record.

The CT specimens were electrically insulated from the loading pins using zirconia sleeves, and within the autoclave, a zirconia washer also isolated the upper pull rod from the internal load frame. The lower pull rod was electrically isolated from the autoclave using a pressure seal and from the loading actuator using an insulating washer. Ground-isolated instrumentation was used for the platinum current and potential probe attachments to the specimen. Testing was performed using servo-electric testing machines equipped with a single stage, low flow servo-valve to ensure optimal (non-noisy) response. Crack growth rates can be considered statistically meaningful when the crack growth increment is at least 10 times the resolution of the technique, which was typically 1 to $5 \mu \mathrm{m}$. Thus, crack length increments were typically $>50 \mu \mathrm{m}$, although for very low growth rate conditions, smaller increments were occasionally used to reduce testing time from several months per datum to several weeks. Generally, the lowest test time for each combination of variables (e.g., stress intensity) was in the order of 2 weeks or 3 mils $(76 \mu \mathrm{m})$ of crack growth. The $R^{2}$ correlation coefficients from linear regression analyses of the crack lengths vs time data from which growth rates are calculated were typically $>0.90$.

Deaerated, de-mineralized water was drawn through a demineralizer and submicron filter to ensure ultra-high purity $(0.055 \mu \mathrm{S} / \mathrm{cm}$ or $18 \mathrm{M} \Omega-\mathrm{cm})$ and then into a glass column (6.4-cm diameter by $183 \mathrm{~cm}$ long). The volume of the column is approximately $4 \mathrm{~L}$, which added to the volume of the autoclave and the piping results on a total

Table IV. Non-irradiated CT Specimens Under Testing at GE GRC

\begin{tabular}{lcll}
\hline Specimen ID & Type of Specimen, Condition & \multicolumn{1}{c}{ Alloy, Heat } & Testing System \\
\hline c642 & 0.5 TCT, as-fabricated & nuclear NFA, experimental & 84SK9 \\
c647 & 0.5 TCT, 21 pct CF & HT-9, V1608621 & 82 SK1 \\
c648 & 0.5 TCT, 23.2 pct CF & APMT, melt 241975 & 84 S3 \\
c649 & 0.5 TCT, 22.6 pct CF & T91, A122133 & 84 S11 \\
\hline
\end{tabular}

$\mathrm{CF}=$ cold forged 
Table V. Current Steam Test Conditions at GE GRC

\begin{tabular}{lccc}
\hline Initial Test Temperatures $\left[\mathrm{K}\left({ }^{\circ} \mathrm{C}\right)\right]$ & Baseline Materials to be Tested & Testing Times $(\mathrm{h})$ & Testing System \\
\hline $1073(800), 1273(1000)$ & Zircaloy-2, T91, NFA, APMT, alloy 33 & $8,24,48,168$ & 84 SK8 \\
\hline
\end{tabular}

volume of solution in the order of 7 to $8 \mathrm{~L}$. A high-pressure pump recirculated the water from the column to the autoclave and back to the column at a rate of approximately 100 to $200 \mathrm{~cm}^{3} / \mathrm{min}$ (which represents two volumes replenishment of the autoclave each hour). The autoclave effluent was back-pressure regulated, then continuously monitored for conductivity and dissolved oxygen. The oxygen concentration was controlled by bubbling gas mixtures blended by mass flow controllers. Impurities of interest (such as $30 \mathrm{ppb}$ sulfate ions as sulfuric acid) were added to the glass column using a metering pump which was controlled via a preset value in the conductivity meter. The crack tests were performed in a 4-L (1 gallon) stainless steel autoclave at $561 \mathrm{~K}\left(288^{\circ} \mathrm{C}\right)$ and 1500 psia $(10.3 \mathrm{MPa})$. The corrosion potentials of the $\mathrm{CT}$ specimen and a $\mathrm{Pt}$ coupon were continuously monitored using a zirconia membrane reference electrode containing copper and copper oxide, whose reference potential is $273 \mathrm{mV}$ higher than the $\mathrm{SHE}$ in pure water at $561 \mathrm{~K}\left(288^{\circ} \mathrm{C}\right)$.

Once the specimen was loaded in the autoclave and connected to the leads, water recirculation started and the temperature and pressure were raised to $561 \mathrm{~K}$ $\left(288^{\circ} \mathrm{C}\right)$ and $1500 \mathrm{psi}(10.3 \mathrm{MPa})$, respectively. Cyclic fatigue generally started at a stress intensity of $25 \mathrm{ksi}{ }_{\text {in }}$ $(27.3 \mathrm{MPa} \sqrt{\mathrm{m}})$ using a trapezoidal wave at a frequency of $0.001 \mathrm{~Hz}$, a load ratio $\left(K_{\min } / K_{\max }\right) R=0.6$, and zero holding time. Ideally, once the crack front propagated 3 mils $(76 \mu \mathrm{m})$ in the first step, a holding time of $9000 \mathrm{~s}$ is applied for each cycle at the highest value of the stress intensity in that cycle. Again, ideally, after the crack advanced another 3 mils $(76 \mu \mathrm{m})$, the stress intensity is kept constant at the highest value (or a static load, $R=1$ ), and the crack advance is typically monitored for a minimum time of 2 weeks or a growth of 3 mils (76 $\mu \mathrm{m})$. Current results show that these ideal situations cannot be fully applied for the alloys in Table IV because they are so resistant to environmental cracking and cracking generally stops growing once the high frequency loading is transitioned to low frequency loading. $[6,27,28]$

Changes in the crack growth rate were also monitored when the water chemistry was changed from pure water to water contaminated with sulfuric acid to give $30 \mathrm{ppb}$ concentration of sulfate ions or chloride ions. Similarly the crack propagation rate was also monitored under oxygenated conditions or normal water conditions (or containing $2 \mathrm{ppm}$ of dissolved oxygen) and under hydrogen water conditions (or containing $63 \mathrm{ppb}$ of dissolved hydrogen). The presence of oxygen or hydrogen controls the corrosion potential of the specimen under test. The crack propagation rate is generally lowered when the corrosion potential is lowered.

\section{Susceptibility to Cracking of Ferritic Alloys}

Stress corrosion cracking testing was initiated on a NFA (specimen c642 in Table IV), containing 14 pet $\mathrm{Cr}$ and oxide dispersion hardened with $\mathrm{Y}_{2} \mathrm{O}_{3}$ in the as-received condition (not cold worked). ${ }^{[6]}$ The in situ fatigue pre-cracking proceeded as anticipated. As the frequency was slowed to transition to intergranular SCC conditions, cracking slowed and ceased. ${ }^{[6]}$ The stress intensity and frequency had to be increased to re-initiate the cracking; however, as the loading frequency decreased, crack growth stalled. This crack growth cessation behavior at low frequencies was observed before for other ferritic steels containing 5, 9, and 13 pct Cr. ${ }^{[29-31]}$

Testing was also initiated on HT9 ferritic steel with 20 pct cold work (specimen c647 in Table IV). The in situ fatigue pre-cracking proceeded well, but after decreasing the frequency to $0.004 \mathrm{~Hz}$ at 260 hours, the crack growth rate slowed and stopped. ${ }^{[6]}$ Testing on the APMT ferritic steel with 20 pct cold work (c648 in Table IV) for APMT are very low compared to known reference materials such as cold-worked nickel-based alloy 600 or type 316 stainless steels. The last specimen mentioned in Table IV is c649 made using T91 ferritic steel with 23 pet cold work. T91 behaved similarly as the other ferritic alloys in the sense that when the conditions were made less aggressive in terms of applied stress intensity and loading frequency, cracking slowed down below measurable rates. ${ }^{[6]}$

All of the ferritic alloys being evaluated for SCC response in this program have excellent resistance to SCC, even under quite aggressive conditions of elevated oxidants (2 ppm dissolved $\mathrm{O}_{2}$ ) and $30 \mathrm{ppb}$ sulfate or chloride (well above that allowed by the BWR water chemistry guidelines).

All crack propagation reported here under cyclic loading condition can be considered fatigue cracking. Only under constant load conditions $(R=1)$, the crack propagation may be recognized as environmentally assisted cracking or SCC. Current results show that ferritic steels containing $\mathrm{Cr}$ are extremely resistant to cracking in high-temperature water.

\section{Behavior of Materials Under Accident Conditions}

Tests are being conducted to determine the relative steam oxidation resistance of advanced steels to compare their behavior with the current zirconium alloys. Table V shows the test conditions for the steam tests. It was also planned to perform the steam tests at $673 \mathrm{~K}$ and $873 \mathrm{~K}\left(400{ }^{\circ} \mathrm{C}\right.$ and $\left.600{ }^{\circ} \mathrm{C}\right)$, but this was later abandoned since even T91 does not have a high (measurable) oxidation rate in steam at the $673 \mathrm{~K}$ to 
$873 \mathrm{~K}\left(400{ }^{\circ} \mathrm{C}\right.$ to $\left.600{ }^{\circ} \mathrm{C}\right)$ temperature range. Initially all the tests were performed in 100 pct steam at a flow rate of $2.5 \mathrm{~g} /$ minute, and eventually, tests may be conducted in mixtures of steam plus hydrogen gas, and steam plus air. Experimental alloys, currently under fabrication, will also be tested for resistance to oxidation in steam and compared to the results from the baseline alloys in Table V. The specimens were flat rectangular measuring approximately $25 \times 8 \times 2.3 \mathrm{~mm}$ with a total exposed area of 5 to $5.3 \mathrm{~cm}^{2}$. The surfaces were ground on wet $\mathrm{SiC}$ paper up to 320 grid finish. All specimens were washed with solvents and dried. The weight (mass) of the specimens was measured with direct reading microbalance at room temperature before and after each test (3 readings), and the mass change due to exposure to steam was calculated.

Figure 4 shows the superheated steam system (SSS). Some of main components include a vertical alumina retort where the five specimens were exposed to steam hanging vertically from a tree. Five thermocouples monitored continuously the temperature next to each specimen. The retort was connected to a steam generator where water was pumped at a rate of $2.5 \mathrm{~g} /$ minute. The ultra-high purity (UHP or $18 \mathrm{M} \Omega$ ) water was deaerated with argon before it was injected into the steam generator using a metering pump with a reciprocating piston design. The steam was forced to flow through four alumina diffusers (Figure 5) to allow for the preheating and homogenization of the steam. The temperature of the retort was controlled by a three-zone furnace. The steam exited the retort through another set of alumina diffusers to avoid back convection of steam onto the specimens. The steam was condensed at the exit of the system, and the volume of water collected was comparable to the amount of water injected into the steam generator.

Once the coupons were inserted in the retort and the system was sealed, the entire system was purged using a constant flow of pure argon $\left(30 \mathrm{~cm}^{3} /\right.$ minute $)$ for 1 to 2 hours, and the gas flow was maintained while heating the chamber (from room temperature to the testing temperature). When the testing temperature was reached, the argon gas flow was stopped and the argon deaerated water injection to the steam generator was started. The top and bottom stainless steel caps of the retort were maintained approximately $423 \mathrm{~K}$ to $453 \mathrm{~K}$

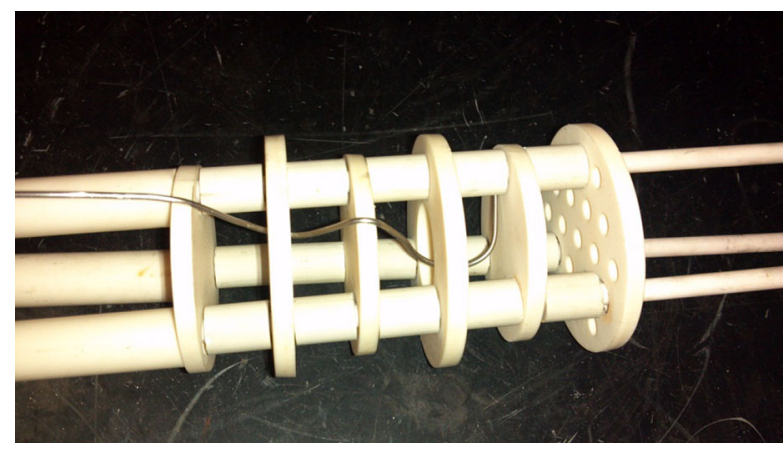

Fig. 5- Set of four alumina diffusers to allow for steam homogenization in the retort.

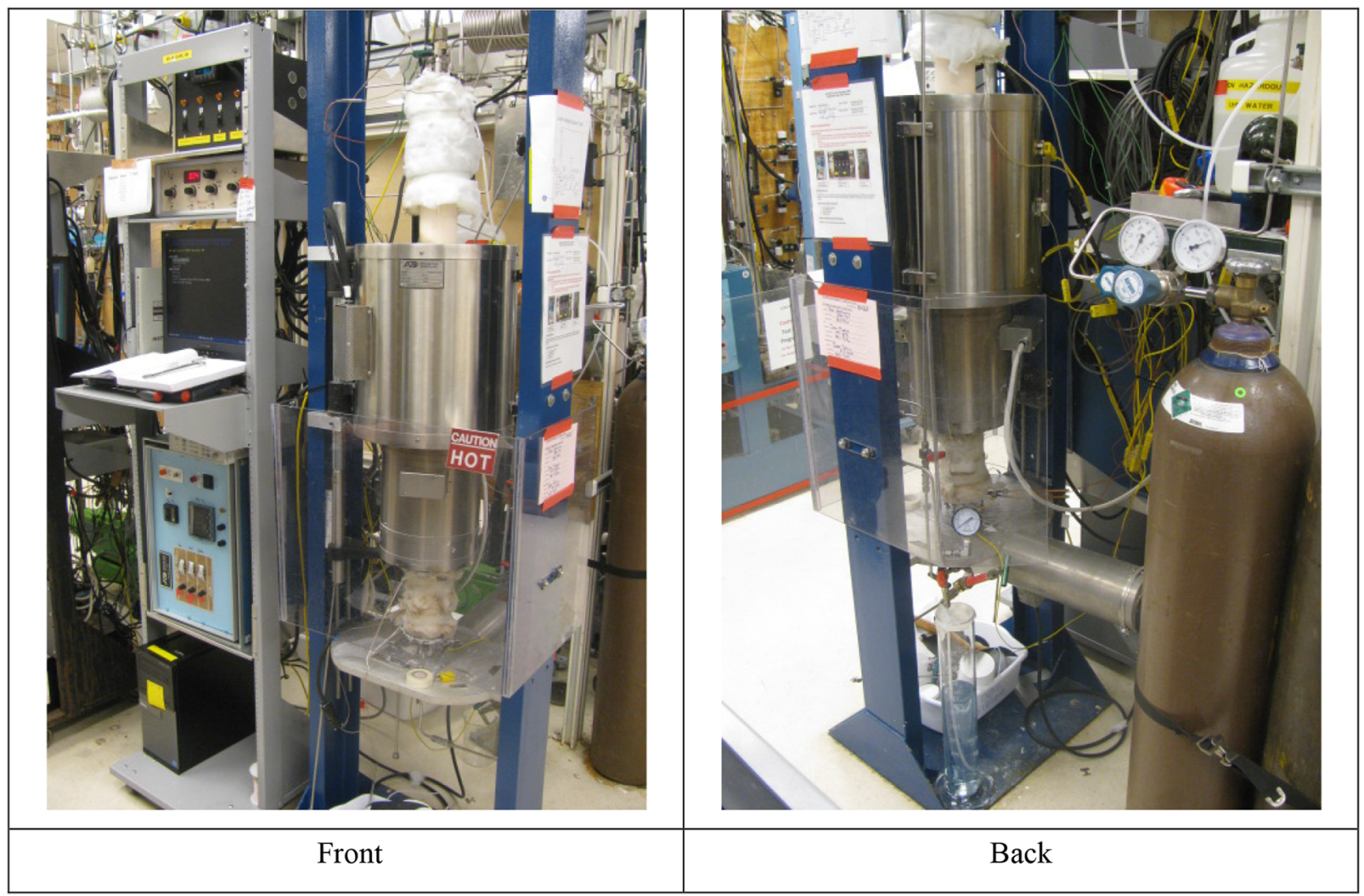

Fig. 4 - Superheated Steam System (SSS). 

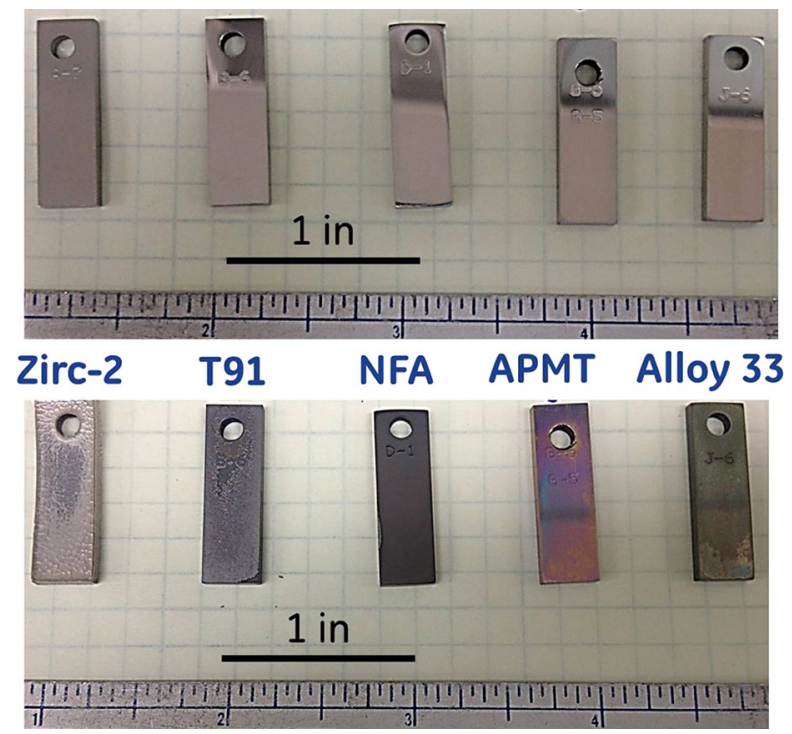

Fig. 6- Specimens before (top) and after (bottom) exposure to 100 pct steam at $1073 \mathrm{~K}\left(800{ }^{\circ} \mathrm{C}\right)$ for $8 \mathrm{~h}$.

$\left(150{ }^{\circ} \mathrm{C}\right.$ to $\left.180{ }^{\circ} \mathrm{C}\right)$ to avoid steam condensation. At the end of the test, the steam injection was stopped, and the testing chamber was cooled down using a flow of dry argon $\left(30 \mathrm{~cm}^{3} /\right.$ minute).

Figure 6 shows the appearance of the coupons before and after 8 hours exposure in steam at $800{ }^{\circ} \mathrm{C}$ with a $2.5 \mathrm{~g} / \mathrm{minute}$ flow rate. After the test, the Zircaloy-2 specimen was slightly bent, perhaps due to the growth of oxides on the surface. The Zircaloy-2 oxide layer presented a white snake-like skin appearance and signs of spallation. Alloy T91 did not show any sign of deformation, but small oxide spallation was evident. The NFA exhibited a uniform black oxide scale whereas APMT and Alloy 33 showed minimal pink and light green discoloration, respectively.

Figure 7 shows the mass gain per surface area as a function of testing time for the five alloys in Table V. The Zircaloy-2 coupon was consumed at the 48 hours testing time; therefore, there are no data in the plot. Figure 7 shows that there were two evident groups of alloys regarding resistance to degradation in steam. Zircaloy-2 and T91 are in Group 1, with a higher oxidation rate, and Group 2 included NFA, APMT, and Alloy 33 with an oxidation rate that was approximately two orders of magnitude lower than for Group 1 . Overall, the highest oxidation rate was for Zircaloy-2 and the lowest for APMT. ${ }^{[32]}$

Figure 8 shows a plot for the weight (mass) change as a function of testing time for the three alloys in Group 2 and the respective fitting according to a power law. The oxidation of the iron-containing alloys seems to follow a parabolic law with an exponent coefficient close to 0.5. The coefficient was higher for the zirconium alloy, suggesting that oxidation was not controlled by diffusion through a protective oxide film on the surface. ${ }^{[32]}$

Figure 9 shows the appearance of the Zircaloy- 2 and APMT coupons in a scanning electron microscope after the exposure to 100 pct steam at $800{ }^{\circ} \mathrm{C}$ for 24 hours. The magnification for Zircaloy-2 is approximately 10

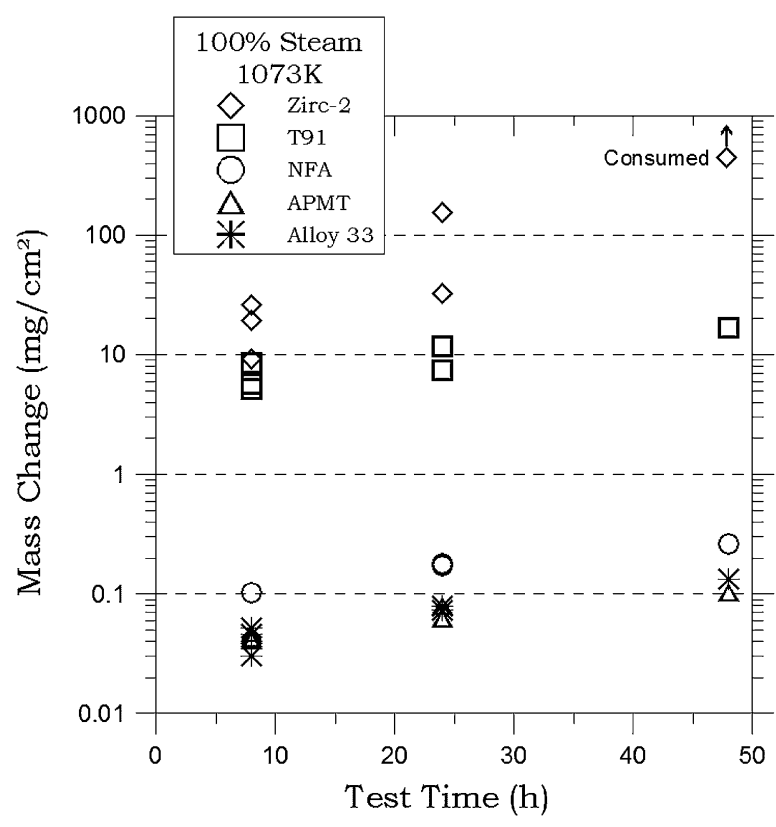

Fig. 7-Mass change as a function of test time in 100 pct steam at $1073 \mathrm{~K}\left(800^{\circ} \mathrm{C}\right)$, Group 1.

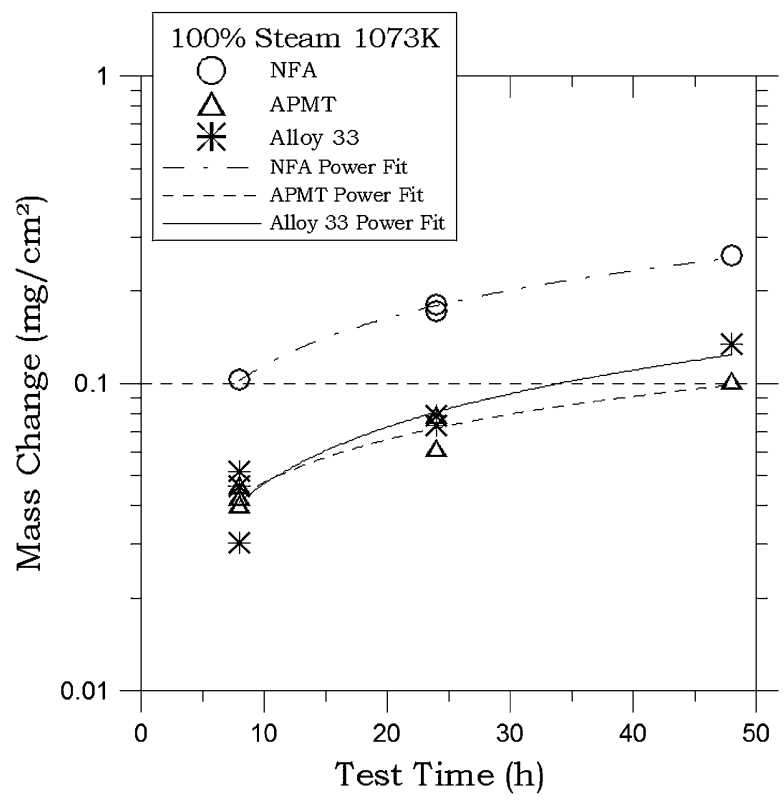

Fig. 8- Mass change as a function of test time in 100 pct steam at $1073 \mathrm{~K}\left(800{ }^{\circ} \mathrm{C}\right)$, Group 2.

times lower than that for APMT. Figure 9 shows the evident difference in oxidation behavior between these two materials. APMT had the lowest oxidation susceptibility in steam since marks from sample preparation are clearly discernible. Zircaloy-2 was completely covered by a cracked oxide film.

\section{DISCUSSION}

Zirconium alloys performed well for almost six decades as cladding material in commercial light water 


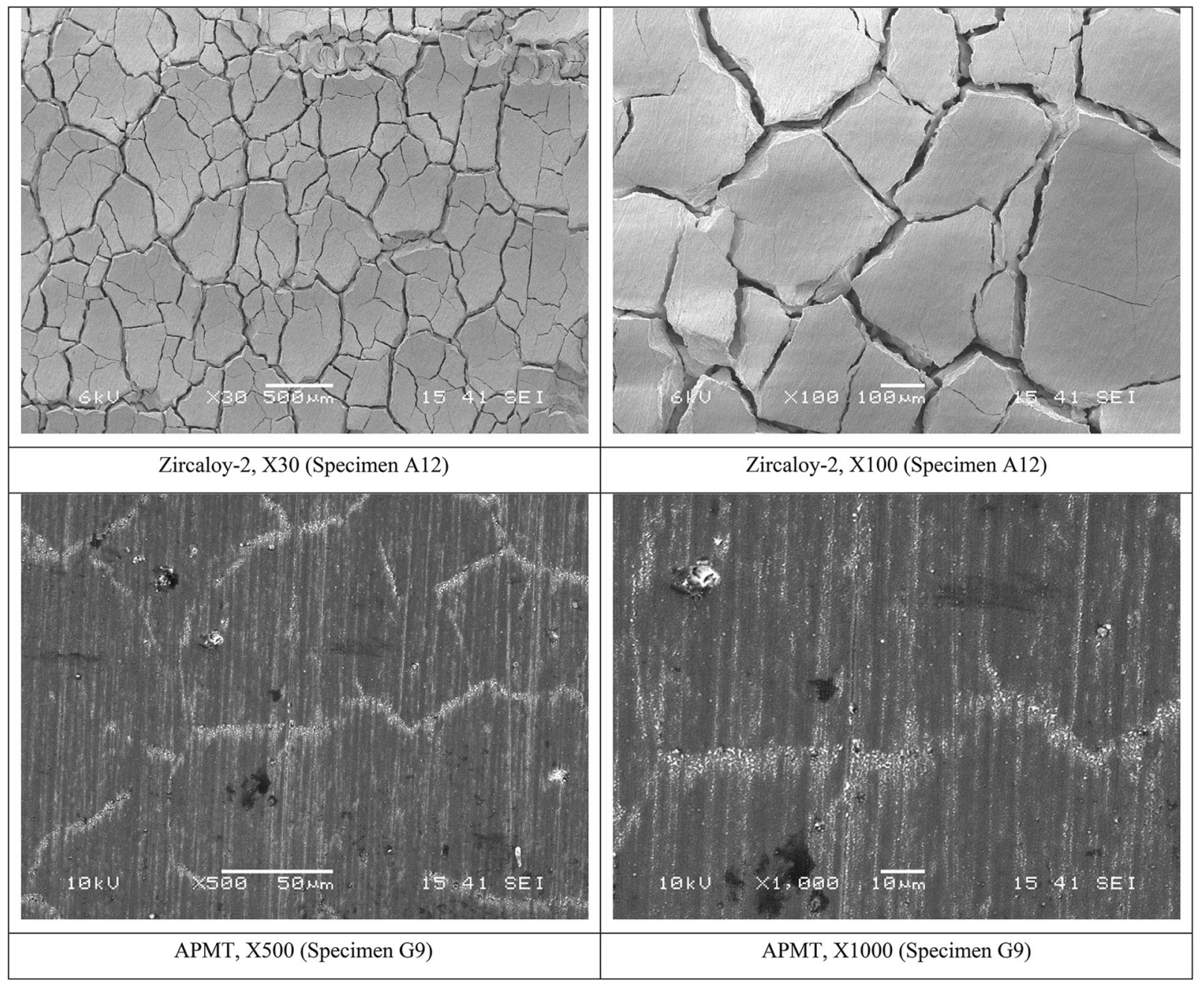

Fig. 9-Appearance of the coupons after testing in 100 pct steam at $1073\left(800{ }^{\circ} \mathrm{C}\right)$ for $24 \mathrm{~h}$.

reactors. The accident at Fukushima showed that under severe accident conditions, zirconium alloys reacted with water and steam producing large amounts of heat and hydrogen. Advanced steel materials (such as $\mathrm{Fe}-\mathrm{Cr}-\mathrm{Al}$ alloys) would offer higher resistance to reaction with steam and hydrogen gas generation. Moreover, $\mathrm{Fe}-\mathrm{Cr}$-Al alloys offer resistance to SCC in high-temperature water, high structural integrity, low creep rates as the temperature increases, low CTE, high thermal conductivity, and enhanced resistance to radiation damage such as material hardening or embrittlement and maintain dimensional stability caused by void and helium driven swelling. Oxide Dispersion-Strengthened steels such as MA956 are resistant to radiation-induced swelling and have improved creep strength and oxidation/corrosion resistance at elevated temperatures compared to conventional steels. ${ }^{[33]}$ It is generally accepted that an irradiated component in a nuclear power plant undergoes three stages during irradiation damage ${ }^{[34]}$ : (1) Primary defect production, (2) Long-range diffusion of the primary defect, and (3) Changes in the properties and dimensions of the component as a consequence of the "new" microstructure. Ferritic/martensitic steels are more resistant to irradiation damage than their cousins the austenitic type 316/304 stainless materials. This is especially true at the lower helium levels or lower dpa ratios. ${ }^{[34]}$ The main explanation of this higher resistance of the ferritic/martensitic materials is due to their bcc structure, which offers a higher self-diffusion coefficient, more traps for helium bubbles and a lower energy for dislocation climb. Another explanation is the lack of nickel in the ferritic/martensitic alloys (thermal neutrons may transmute $\mathrm{Ni}$ into helium). ${ }^{[34]}$

One of the attributes of an improved cladding material is that it may also retain fission products under normal operation conditions (as the current zirconium alloys normally do). Moreover, the advanced steel cladding would also have improved retention of fission products under accident conditions over the current zirconium alloys. That is, the candidate material may not breach releasing fission products to the external environment. Breaching of the cladding may be produced from the OD or water side via a mechanism of SCC or environmentally assisted cracking or from the ID of the cladding or fuel side also via a mechanism of SCC. Zirconium alloys are resistant to cracking from 
the water side under normal operation conditions ${ }^{[35]}$ but may suffer cracking from the fuel side due to a combined effect of hoop stresses and iodine. ${ }^{[36]}$ Zirconium alloys also react with hydrogen to form internal hydrides, which may render the cladding brittle and subject to enhanced cracking susceptibility. ${ }^{[36]}$ On the adverse side, $\mathrm{Fe}-\mathrm{Cr}-\mathrm{Al}$ alloys may release more tritium into the coolant because the elements of the alloy do not react with hydrogen to form stable hydrides.

Current zirconium-based alloys sometimes suffer from failure from the pellet side of the cladding (ID of the tubing) due to the phenomenon of pellet cladding interaction (PCI). ${ }^{[37]}$ Zirconium-based alloys are susceptible to cracking when there is fuel swelling that imparts hoop stresses in the ID of the cladding, which with the presence of fission products such as iodine, may develop cracks from the ID of the zirconium alloy cladding. ${ }^{[37]}$ At this moment, it is not known if ferritic steels are susceptible to any form of PCI, including chemical and mechanical interactions.

The great advantage of the advanced steels (such as $\mathrm{Fe}-\mathrm{Cr}-\mathrm{Al}$ alloy) is their outstanding resistance to reaction with steam under accident conditions. ${ }^{[4]}$ Previous work from the 1960s showed compatibility between this type of steel and the $\mathrm{UO}_{2}$ fuel, especially if the cladding material is pre-oxidized. ${ }^{[38]}$

The great advantage of zirconium-based alloys for fuel cladding is their transparency to neutrons and the lower emission of tritium in the coolant when zirconium components are used in the reactor. Current calculations show that to maintain the current uranium oxide fuel enrichment, the wall thickness of a $\mathrm{Fe}-\mathrm{Cr}-\mathrm{Al}$ cladding may need to be in the range of 300 to $400 \mu \mathrm{m}$ (12 to 16 mils). ${ }^{[4,5,39]}$ When stainless steels were used in the past as fuel cladding, a higher release of tritium was reported. ${ }^{[40]}$ Studies are currently being conducted on measures to minimize the release of tritium in the coolant in the case of using $\mathrm{Fe}-\mathrm{Cr}-\mathrm{Al}$ alloys. Current studies are also under way on the fabrication viability of Fe-Cr-Al alloys into long thin-walled tubes and on the overall economic impact of the use of $\mathrm{Fe}-\mathrm{Cr}-\mathrm{Al}$ cladding on the price of electricity. Other studies include the effect of irradiation on the cladding properties and the chemical and mechanical interaction between cladding and fuel pellet during rodlet exposure tests in the Advanced Test Reactor at Idaho National Laboratory.

\section{SUMMARY AND CONCLUSIONS}

1) Advanced ferritic steels are being characterized as accident tolerant fuel cladding materials for current commercial nuclear reactors

2) The advanced steels need to perform as good as zirconium alloys under reactor normal operation conditions and better than zirconium alloys under accident conditions such as LOCA

3) Results show that advanced ferritic steels such as Fe-Cr-Al alloys are highly resistant to SCC in high-temperature water in simulated normal operation conditions
4) Advanced ferritic steels suffer low general corrosion rates in high-temperature water at $288^{\circ} \mathrm{C}$

5) The largest improvement that advanced $\mathrm{Fe}-\mathrm{Cr}-\mathrm{Al}$ steels can offer is their outstanding resistance to reaction with steam under accident scenarios

6) Current studies include the evaluation of neutronics, tritium release, and economic impact on the cost of electricity for the case of a Fe-Cr-Al cladding material.

\section{ACKNOWLEDGMENTS}

The technical expertise of R. J. Blair, F. Wagenbaugh, and P. J. Martiniano is gratefully acknowledged. This material is based upon work supported by the Dept. of Energy [National Nuclear Security Administration] under Award Number DENE0000568 and Award Number DE-NE00082 21. This report was prepared as an account of work sponsored by an agency of the United States Government. Neither the United States Government nor any agency thereof, nor any of their employees makes any warranty, express or implied, or assumes any legal liability or responsibility for the accuracy, completeness, or usefulness of any information, apparatus, product, or process disclosed, or represents that its use would not infringe privately owned rights. Reference herein to any specific commercial product, process, or service by trade name, trademark, manufacturer, or otherwise does not necessarily constitute or imply its endorsement, recommendation, or favoring by the United States Government or any agency thereof. The views and opinions of authors expressed herein do not necessarily state or reflect those of the United States Government or any agency thereof.

\section{REFERENCES}

1. J. Carmack and F. Goldner: J. Nucl. Mater., 2014, vol. 448 (1-3), p. 373 .

2. R.G. Hewlett and F. Duncan: Nuclear Navy 1946-1962, The University of Chicago Press, Chicago, 1974.

3. S.M. Bragg-Sitton: Report INL/MIS-12-25696, Idaho National Laboratory, 2012.

4. K.A. Terrani, S.J. Zinkle, and L.L. Snead: J. Nucl. Mater., 2014, vol. 448, pp. 420-35.

5. N.M. George, K.A. Terrani, and J.J. Powers: Report ORNL/ TM-2013/121, Oak Ridge National Laboratory, 2013.

6. P.L. Andresen, R.B. Rebak, and E.J. Dolley: Paper C2014-3760, Corrosion/2014, NACE International, 2014.

7. J.E. Rivera, and J.E. Meyer: Energy Laboratory Report No. MIT-EL, 1980.

8. A.J. Sedriks: Corrosion of Stainless Steels, 2nd ed., Wiley, New York, 1996.

9. A.P. Bond, J.D. Marshall, and H.J. Dundas: Stress Corrosion Testing, ASTM STP 425, American Society for Testing Materials, p. 116-23 1967.

10. P.L. Andresen: Paper C2012-0001929, Corrosion/2012, NACE International, 2012.

11. H.M. Chung and W.J. Shack: NUREG/CR-6892, Argonne National Laboratory and U.S. Nuclear Regulatory Commission, Office of Nuclear Regulatory Research, Washington, DC, 2006. 
12. J.M. Cookson, R.D. Carter, Jr., D.L. Damcott, M. Atzmon, and G.S. Was: J. Nucl. Mater., 1993, vol. 202, pp. 104-121.

13. A.J. Jacobs, G.P. Wozadlo, K. Nakata, S. Kasahara, T. Okada, S. Kawano, S. Suzuki: in Proc. 6th International Symposium on Environmental Degradation of Materials in Nuclear Power Systems-Water Reactors, Minerals, The Minerals, Metals \& Materials Society TMS, Warrendale, PA, pp. 597-606, 1993.

14. G.S. Was: in Proceedings of the 11th International Conference on Environmental Degradation of Materials in Nuclear Systems, pp. 965-85, 2003.

15. S.M. Bruemmer: Proc. 10th Int. Conf. Environmental Degradation of Materials in Nuclear Power Systems -Water Reactors, NACE International, 2002.

16. G.S. Was, J. Busby, and P.L. Andresen: in ASM Handbook, Volume 13C: Corrosion: Environments and Industries, S.D. Cramer and B.S. Covino, Jr., eds., ASM International, Materials Park, pp. $386-414,2006$

17. T. Yonezawa, K. Fujimoto, T. Iwamura, and S. Nishida: in Environmentally Assisted Cracking: Predictive Methods for Risk Assessment and Evaluation of Materials, Equipment, and Structures, ASTM 1401, R.D. Kane, ed, American Society for Testing and Materials, pp. 224-38, 2000.

18. A. Hojná: Corrosion, 2013, vol. 69 (10), pp. 964-74.

19. B. Raj and M. Vijayalakshmi: JOM, 2010, vol. 62 (9), pp. 75-83.

20. C.L. Whitmarsch: Report ORNL-3281, UC-80 - Reactor Technology TID-4500, 1962

21. L. Baker and L.C. Just: Studies of Metal-Water Reactions at High Temperatures, ANL-6548, Argonne National Laboratory, 1962.

22. S. Leistikow and G. Schanz: Nucl. Eng. Des., 1987, vol. 103 (1), pp. $65-84$.

23. IAEA, International Atomic Energy Agency: Final Report EUR $14037 \mathrm{EN}, 1992$.

24. C. Grandjean and G. Hache: IRSN Report SEMCA 2008-093, 2008.

25. B.A. Pint, K.A. Terrani, M.P. Brady, T. Cheng, and J.R. Keiser: $J$. Nucl. Mater., 2013, vol. 440, pp. 420-27.
26. E.J. Opila: Mater. Sci. Forum, 2004, vols. 461-464, pp. 765-74.

27. T. Cheng, J.R. Keiser, M.P. Brady, K.A. Terrani, and B.A. Pint: $J$. Nucl. Mater., 2012, vol. 427 (1-3), pp. 396-400.

28. R.B. Rebak, Y.-P. Lin, and Y.-J. Kim: in Proceedings of the 14th International Conference on Environmental Degradation of Materials in Nuclear Power Systems-Water Reactors, American Nuclear Society, 2009, pp. 1400-406.

29. P.L. Andresen, T.B. Jurewicz, and R.B. Rebak: Paper C2012-0001181, Corrosion/2012, NACE International, 2012.

30. R.B. Rebak, P.L. Andresen, R.J. Blair, and E.J. Dolley: Paper C2013-2599, Corrosion/2013, NACE International, 2013.

31. R.B. Rebak: Paper PVP2013-97352, ASME PVP Conference Integrity Issues in SCC and Corrosion Fatigue, 2013.

32. R.B. Rebak, P.L. Andresen, and E.J. Dolley: in Advances in Materials Science for Environmental and Energy Technologies III, The American Ceramic Society, 2014.vol. 250, pp. 111-26.

33. L.L. Hsiung, M.J. Fluss, S.J. Tumey, B.W. Choi, Y. Serruys, F. Willaime, and A. Kimura: Phys. Rev.B, 2010, vol. 82, p. 184103.

34. G.R. Odette, M.J. Alinger, and B.D. Wirth: Annu. Rev. Mater. Res., 2008, vol. 38, pp. 471-503.

35. C. Lemaignan: in ASM Metals Handbook, Volume 13C: Corrosion: Environments and Industries, S.D. Cramer and B.S. Covino, Jr., eds., ASM International, Materials Park, pp. 415-20, 2006.

36. B. Cox: in Advances in Corrosion Science and Technology, Volume 5, Edited by M.G. Fontana and R.W. Staehle, Plenum Press, New York, pp 173-391 (1976).

37. B. Cox: J. Nucl. Mater., 1990, vol. 172, pp. 249-292.

38. H.S. Edwards and K.M. Bohlander: Technical Report GEMP-1004 General Electric Co., [Cincinnati, Ohio], Nuclear Materials and Propulsion Operation, 1969.

39. N.M. George, K. Terrani, J. Powers, A. Worrall, and I. Maldonado: Ann. Nucl. Energy, 2015, vol. 75, pp. 703-712.

40. EPRI-The Electric Power Research Institute, Report NP-2642, Palo Alto, 1982 